DOI: $10.14720 /$ aas.2016.107.2.04

Agrovoc descriptors: Trialeurodes vaporariorum, new technology, zinc, insecticidal properties, Beauveria bassiana, entomogenous fungi, plant pests, biological control agents, Insecticides, bioassay

Agris category code: $\mathrm{H} 01, \mathrm{H} 10$

\title{
Insecticidal effects of zinc oxide nanoparticles and Beauveria bassiana TS11 on Trialeurodes vaporariorum (Westwood, 1856) (Hemiptera: Aleyrodidae)
}

\author{
Zahra KHOOSHE-BAST $^{1}$, Najmeh SAHEBZADEH ${ }^{1 *}$, Mansour GHAFFARI-MOGHADDAM ${ }^{2}$, Ali MIRSHEKAR $^{1}$
}

Received Janury 15, 2016; accepted April 29, 2016.

Delo je prispelo 15. januarja 2016, sprejeto 29. aprila 2016.

\begin{abstract}
Greenhouse whitefly, Trialeurodes vaporariorum is a major pest of horticultural and ornamental plants and is usually controlled with insecticides or biological control agents. In the current study, we examined the effects of synthesized zinc oxide nanoparticles (ZnO NPs) and Beauveria bassiana TS11 on $T$. vaporariorum adults. ZnO NPs were synthesized by precipitation method. Field emission scanning electron microscope images indicated that $\mathrm{ZnO}$ NPs were noncompacted uniformly. X-ray diffraction results confirmed the hexagonal wurtzite structure of $\mathrm{ZnO}$ NPs. Fourier transform infrared analysis showed an intense absorption peak at a range of 434-555 $\mathrm{cm}^{-1}$ related to $\mathrm{Zn}-\mathrm{O}$ bond. In bioassays, adults were exposed to different concentrations of ZnO NPs $(3,5,10$, $\left.15,20 \mathrm{mg} \mathrm{l}^{-1}\right)$ and fungi $\left(10^{4}, 10^{5}, 10^{6}, 10^{7}, 10^{8}\right.$ spores $\left.\mathrm{ml}^{-1}\right)$. $\mathrm{LC}_{50}$ values for $\mathrm{ZnO} \mathrm{NPs}$ and fungi were $7.35 \mathrm{mg}^{-1}$ and $3.28 \times 10^{5}$ spores $\mathrm{ml}^{-1}$, respectively. Mortality rates obtained with $\mathrm{ZnO}$ NPs and fungi at the highest concentration were $91.6 \%$ and $88.8 \%$, respectively. The results indicate a positive effect of $\mathrm{ZnO}$ NPs and B. bassiana TS11on adults. The current study was conducted under laboratory conditions, therefore, more studies are needed in field.
\end{abstract}

Key words: entomopathogenic fungus; nanoparticle; metal oxide; insecticide; bioassay

\section{IZVLEČEK}

\author{
INSEKTICIDNI UČINKI NANO DELCEV \\ CINKOVEGA OKSIDA IN TROSOV GLIVE Beauveria \\ bassiana TS11 NA RASTLINJAKOVEGA ŠČITKARJA \\ (Trialeurodes vaporariorum (Westwood, 1856) (Hemiptera: \\ Aleyrodidae))
}

Rastlinjakov ščitkar (Trialeurodes vaporariorum) je eden izmed glavnih škodljivcev hortikulturnih rastlin in se ga navadno zatira $\mathrm{z}$ insekticidi ali biološkimi agensi. $\mathrm{V}$ tej raziskavi smo preučevali učinke nano delcev cinkovega oksida (ZnO NP) in glive Beauveria bassiana TS11 na njegove odrasle osebke. ZnO NP je bil pripravljen z metodo usedanja. Analiza nano delcev $\mathrm{ZnO} \mathrm{z}$ vrstičnim elektronskim mikroskopom je pokazala njihovo neizenačenost. Njihova nadaljna analiza $\mathrm{z}$ rentgenskimi žarki je potrdila njihovo heksagonalno strukturo. Analiza s Fourierjevo prosevno infrardečo spektrometrijo je pokazala močan absorpcijski vrh v območju 434-555 $\mathrm{cm}^{-1}$, ki se je nanašal na $\mathrm{Zn}-\mathrm{O}$ vez. $\mathrm{V}$ preiskusu smrtnosti so bili odrasli osebki ščitkarja izpostavljeni različnim koncentracijam nano delcev $\mathrm{ZnO}(3,5$, $\left.10,15,20 \mathrm{mg} \mathrm{l}^{-1}\right)$ in trosov glive $\left(10^{4}, 10^{5}, 10^{6}, 10^{7}, 10^{8}\right.$ spor $\mathrm{ml}^{-1}$ ). Vrednosti $\mathrm{LC}_{50}$ so bile za nano delce $\mathrm{ZnO} 7.35 \mathrm{mg} \mathrm{l}^{-1}$ in $3.28 \times 10^{5} \mathrm{ml}^{-1}$ za trose glive. Smrtnost, ki je bila dosežena pri največjih koncentracijah nano delcev $\mathrm{ZnO}$ in trosov glive je znašala $91.6 \%$ in $88.8 \%$. Ti izsledki kažejo pozitivni učinek obeh pripravkov na smrtnost odraslih osebkov rastlinjakovega ščitkarja. Glede na to, da je bila raziskava opravljena $\mathrm{v}$ laboratoriju je potrebno $\mathrm{v}$ bodoče opraviti še več raziskav $\mathrm{v}$ realnih razmerah.

Ključne besede: entomopatogene glive; nano delci; kovinski oksid; insekticid; biotest

\footnotetext{
Department of Plant Protection, Faculty of Agriculture, University of Zabol, Zabol, Iran; * correspondence: n.sahebzadeh@uoz.ac.ir

Department of Chemistry, Faculty of Science, University of Zabol, Zabol, Iran
} 


\section{INTRODUCTION}

The greenhouse whitefly, Trialeurodes vaporariorum (Westwood, 1856) (Hemiptera, Aleyrodidae), is a globally distributed pest because of its quick multiplication, virus transmission, sap puncture, secretion of honeydew and promotion of sooty molds on the host leaves (Guzman et al., 1997). Excessive use of chemical pesticides and increased resistance to insecticides (Whalon et al., 2008), environmental pollutions, impacts on human health and other organisms and finally pesticides residues in nature and agricultural products have provided great impetus to the development of alternative techniques of pest control (Van Lenteren et al., 1996; Laznik et al., 2011; Sandhu et al., 2012).

Recent progress in nano-technology has provided new opportunities in the fields of science such as agriculture (Chaudhry et al., 2008). Application of nanomaterials can revolutionize agriculture by developing potential and effective methods for pest management (Rai and Ingle, 2012). Some studies have reported the toxic effects of metal nanoparticles (such as silver, zinc, aluminum, and titanium oxide) on plants, crustaceans, bacteria, fungi, pathogens and pests (Elchiguerra et al., 2005; Goswami et al., 2010; Kairyte et al., 2013; Kirthi et al., 2011; Manzo et al., 2011; Morones et al., 2005; Reddy et al., 2007; Rouhani et al., 2012; Samuel and Guggenbichler 2004). Among them, zinc oxide $(\mathrm{ZnO})$ nanoparticle is best-known compound (Mitra et al., 2012) commonly used as agricultural fungicide (Waxman 1998). Furthermore, cytotoxicity in eukaryotic cells (Gupta and Gupta, 2005; Magrez et al., 2006), preventing growth in prokaryotic cells (Brayner et al., 2006), bactericidal and fungicidal activity and low effects of $\mathrm{ZnO}$ NPs on human cells have also been reported (Kairyte et al., 2013). Low cost synthesis, protective effect against ultraviolet (UV) rays, biocompatibility and non-toxicity has attracted the attention of many researchers (Brayner et al., 2006; Zhang et al., 2007; Ahmad Umar et al., 2009). In spite of the studies performed on NPs to control limiting factors in ecosystems, little research has been carried out to investigate the toxicity effect of $\mathrm{ZnO}$ nanoparticles on agricultural pests.

In addition to nanotechnology, biological control is another alternative method to chemical pesticides due to its non-toxicity for human and other nontarget organisms, decreasing toxic residue in nature and food (Lacey et al., 2001). Aleyrodidae entomopathogens are limited to fungi since they are capable to penetrate the insect cuticle of sucking insects such as Aphis gossypii (Glover, 1877) (Gurulingappa et al., 2011), Rhynchophorus ferrugineus (Olivier, 1790) (Sewify et al., 2009), Laniifera cyclades (Druce, 1895) (Lozano-Gutierrz and Espana-Luna, 2008) and Galleria melonella (Linnaeus, 1758) (El-Sinary and Rizk, 2007). Among entomopathogenic fungi, Beauveria bassiana (Bals.-Criv.) Vuill. with broad host range is known as an effective organism to control medical and agricultural pests (Inglis et al., 2001). The aim of this research was to investigate the insecticidal activity of synthesized $\mathrm{ZnO}$ nanoparticles and $B$. bassiana TS11 on Trialeurodes vaporariorum under greenhouse conditions.

\section{MATERIALS AND METHODS}

\subsection{Preparation of $\mathrm{ZnO}$ nanoparticles by precipitation}

To prepare $\mathrm{ZnO}$ nanoparticles, first, $1 \mathrm{~g}$ of zinc oxide powder was dissolved in $100 \mathrm{ml}$ of $1 \%$ acetic acid oxidizing zinc-to-zinc cations. Then, the mixture was sonicated for 30 minutes. After 5 minutes, sodium hydroxide solution $(1 \mathrm{M})$ was added drop wise to the above solution until the $\mathrm{pH}$ of solution reached to 10 . The solution was heated in a water bath at $40-80{ }^{\circ} \mathrm{C}$ for 3 hours. Then, it was filtered through a filter paper and the precipitate was washed twice with distilled water. Finally, it was placed in an oven at $50{ }^{\circ} \mathrm{C}$ for 1 hour to form $\mathrm{ZnO}$ nanoparticles (Abdelhady, 2012). 


\subsection{Characterization of the synthesized $\mathrm{ZnO}$ nanoparticles}

An analysis of nanoparticles was performed using Fourier transform infrared (FTIR) spectrometer (Bruker Optics Ft Tensor 27, Germany) by $\mathrm{KBr}$ (potassium bromide). The XRD analyses were performed using Bruker D8 X-ray diffractometer. FESEM (Hitachi S4160) analysis was carried out to observe the morphology of $\mathrm{ZnO}$ nanoparticles.

\subsection{Entomopathogenic fungus culture and suspension preparation}

Isolate TS11 of fungus B. bassiana isolate TS11 was obtained from Department of Plant Protection, University of Tehran, Iran. The fungus was inoculated on Sabouraud dextrose agar (SDA) medium in $8 \mathrm{~cm}$ Petri dishes and grown at $27^{\circ} \mathrm{C}$. After 12 days, to prepare inoculum, $10 \mathrm{ml}$ of sterile distilled water containing $0.2 \%$ of aqueous Tween 20 solution (Sigma Alrdich, Spain) was spread over the petri dishes using a suitable tool. The suspension was filtered through cheesecloth to separate conidia from remnants of the mycelium. The suspension was vortexed to separate spores from each other and to prevent mass formation during counting. Haemocytometer was used to count spores and prepare various concentrations of spores per unit volume.

\subsection{Insect rearing}

Adults of T. vaporariorum were collected from the surface of cucumber leaves (Cucumis sativus L) attacked with this pest from Sistan region $\left(31.0256^{\circ} \mathrm{N}, \quad 61.5011^{\circ} \mathrm{E}\right.$, and average of 480 meters above the sea level) located in the east of Iran. The adults were reared on young green bean (Phaseolus vulgaris L.) plants in a laboratory greenhouse (University of Zabol, Zabol, Iran) under controlled conditions $\left(27 \pm 2{ }^{\circ} \mathrm{C}, 60 \pm 10 \%\right.$ $\mathrm{RH}$ and a photoperiod of 16:8 (L: D) h). In order to perform bioassays, Muniz and Nombela's method (2001) was followed.

\subsection{Bioassay and determination of lethal concentration of $\mathrm{ZnO}$ nanoparticles}

To find concentrations with $10-90 \%$ mortality, primary tests were done with concentration ranges between 1-30 $\mathrm{mg}^{-1}$ of the synthesized $\mathrm{ZnO}$ NPs. 20 adults of $T$. vaporariorum with same age were considered for each concentration. Following method was carried out in both primary and final tests. To diminish the activity of greenhouse whiteflies, the numbers of insects per concentration were released into the plastic tubes using an aspirator. The tubes were then put in the incubator at $5{ }^{\circ} \mathrm{C}$ for 2 minutes (personal observations). Then, the specific numbers of insects were transferred to glass petri dishes already with filter paper-covered floor, but before getting started, the desired concentrations of $5 \mathrm{ml}$ were sprayed on them using a $5 \mathrm{ml}$ handy sprayer. To avoid precipitation of nanoparticles in solutions, before spraying, all the prepared concentrations were sonicated for 10 minutes (Velayutham et al., 2013). After finishing, the insects were transferred to leaf cages installed over green bean leaves. The numbers of dead insects were counted after 24 hours and mortality was computed after three replications. In this experiment, distilled water was used for control.

\subsection{Bioassays of B. bassiana TS11}

Preliminary bioassays were conducted on adult insects with $10^{2}-10^{10}$ spores $\mathrm{ml}^{-1}$ concentrations of B. bassiana TS11. Concentrations of $10^{4}$ and $10^{8}$ spores $/ \mathrm{ml}$ caused 30 and $80 \%$ mortality were selected as minimum and maximum concentrations, respectively and between them three logarithmic concentrations of $10^{5}, 10^{6}$ and $10^{7}$ spores $/ \mathrm{ml}$ were selected for final bioassays. In each treatment, $0.2 \%$ Tween 20 (Sigma Aldrich, Spain) as an emulsifying agent was added to suspension of fungal conidia. Distilled water containing $0.2 \%$ Tween 20 was used as control treatment. The experiments were conducted in a completely randomized design with three replicates of treatments.

Bioassays in these experiments started with control treatment; next, they were continued from lowest level of concentration to the highest level. In order to infect the insects, similar as in bioassay procedure with $\mathrm{ZnO}$ nanoparticles, the insects were first deactivated at $5{ }^{\circ} \mathrm{C}(2 \mathrm{~min}) .30$ adult whiteflies were considered for each concentration. The specific numbers of the insects were individually placed in glass petri dishes with filter papercovered floor; the desired spore concentrations were then sprayed on insects $(5 \mathrm{ml}$ of each concentration using a $5 \mathrm{ml}$ handy sprayer). After application of fungal suspension, whiteflies were placed inside glasses containing water-agar and 
green bean leaf. In order to provide moisture for primary germination of spores, the glasses were put in the germinator $\left(27^{\circ} \mathrm{C}, 80 \% \mathrm{RH}\right)$ for 24 hours. After 24 hours, whiteflies were released into leaf cages installed over young green bean leaves outside germinator and mortality of insects was recorded under controlled condition $\left(27 \pm 2{ }^{\circ} \mathrm{C}\right.$,
$60 \pm 10 \% \mathrm{RH}$, a photoperiod of $16: 8$ ([L: D] h) for 10 days.

\subsection{Statistical analysis}

To determine $\mathrm{LC}_{50}$ and $\mathrm{LC}_{25}$, SPSS 21 software (IBM, New York, US) with confidence limits of $95 \%$ and Probit analysis were used.

\section{RESULTS AND DISCUSSION}

The current study presents the results of insecticidal activity of the synthesized $\mathrm{ZnO}$ nanoparticles after 24 hours and pathogenicity of entomopathogenic B.bassiana TS11 after 10 days.
Mortality rate of insects was evaluated using Probit analysis. Table 1 illustrates values of $\mathrm{LC}_{25}$ and $\mathrm{LC}_{50}$, confidence limits (CL), slope and Chi-square $\left(\chi^{2}\right)$ for $\mathrm{ZnO}$ nanoparticles and B.bassiana TS11.

Table 1: Mean values of $T$. vaporariorum mortality by lethal concentrations of $\mathrm{ZnO}$ nanoparticles and B. bassiana TS11

\begin{tabular}{|c|c|c|c|c|c|}
\hline Test Samples & Intercept $\pm s_{e}$ & $\mathrm{LC}_{25}(95 \% \mathrm{CL})$ & $\mathrm{LC}_{50}(95 \% \mathrm{CL})$ & Slope $\pm s_{e}$ & $\chi^{2}(\mathrm{df})$ \\
\hline $\mathrm{ZnO}$ nanoparticles & $-2.007 \pm 0.264$ & $\begin{array}{c}3.76 \mathrm{mg} \mathrm{l}^{-1} \\
(2.80-4.61)\end{array}$ & $\begin{array}{c}7.35 \mathrm{mg} \mathrm{l}^{-1} \\
(6.21-8.58)\end{array}$ & $2.32 \pm 0.27$ & $5.18(3)$ \\
\hline B. bassiana TS11 & $-2.499 \pm 0.288$ & $\begin{array}{l}0.106 \times 10^{5} \text { spores } \mathrm{ml}^{-1} \\
\left(0.28 \times 10^{4}-0.26 \times 10^{5}\right)\end{array}$ & $\begin{array}{c}3.28 \times 10^{5} \text { spores } \mathrm{ml}^{-1} \\
\left(1.62 \times 10^{5}-6.2 \times 10^{5}\right)\end{array}$ & $0.453 \pm 0.048$ & $1.37(3)$ \\
\hline
\end{tabular}

$\mathrm{LC}_{25}$ and $\mathrm{LC}_{50}$ : lethal concentration that kills 25 and $50 \%$ of $T$. vaporariorum after exposure to nanoparticle concentration ( $\mathrm{mg} \mathrm{l}^{-1}$ ) and B.bassiana TS11 (spores $\mathrm{ml}^{-1}$ ), respectively. The estimated lethal concentration values (mg/l for ZnO NPs and spores $\mathrm{ml}^{-1}$ for B. bassiana TS11 for treatment was given using Probit analysis. Values in parentheses indicate $95 \%$ confidence limits (CL). Df and $s_{e}$ refers to degrees of freedom and standard error, respectively.

\subsection{ZnO nanoparticles}

Insecticidal activity of the synthesized $\mathrm{ZnO}$ nanoparticles revealed that values of $\mathrm{LC}_{50}$ and $\mathrm{LC}_{25}$ (7.35 and $3.76 \mathrm{mg} \mathrm{l}^{-1}$, respectively) had significant lethal effects on T. vaporariorum adults. Statistical results showed a significant difference between concentrations of $\mathrm{ZnO}$ nanoparticles at $5 \%$ level.
Moreover, mortality rate depended on concentration, in other words, as concentration increased, lethality also significantly increased. Mortality rates of concentrations of 3, 5, 1015 and $20 \mathrm{mg} \mathrm{l}^{-1}$ were $21.6 \%, 35 \%, 53.3 \%, 73.3 \%$ and $91.6 \%$, respectively (Figure 1 ). 


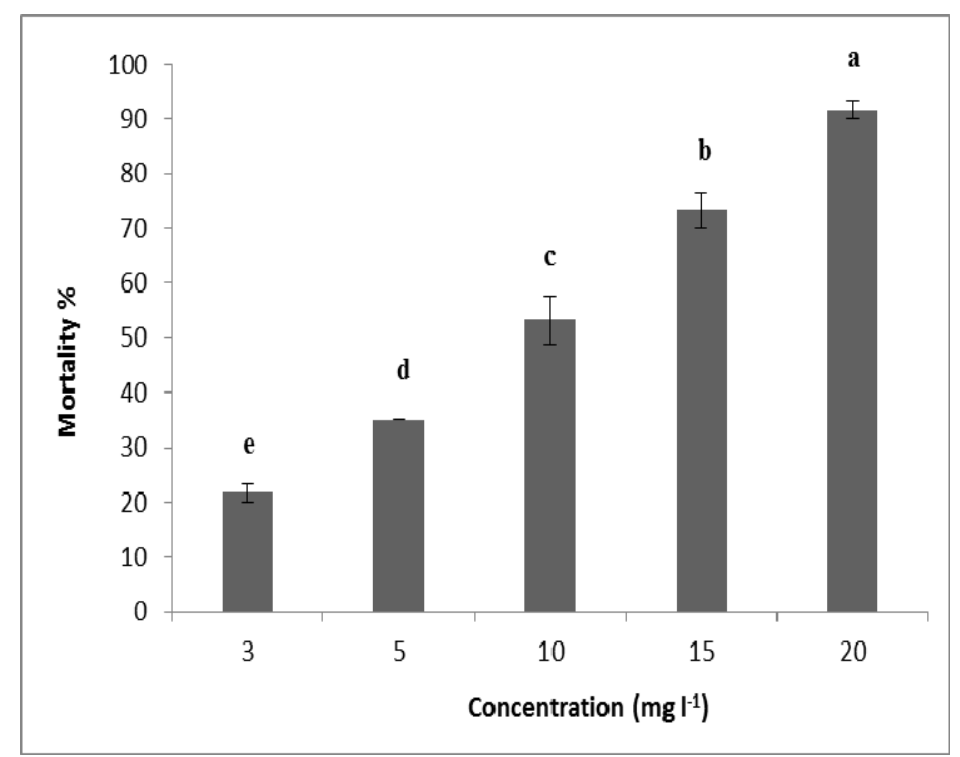

Figure 1: Mortality of T. vaporariorum adults, 24 hours after application of $\mathrm{ZnO}$ nanoparticles. Values followed by same letter indicate there is no overlap in $95 \%$ confidence interval.

The FESEM images taken from $\mathrm{ZnO}$ nanoparticles sample indicated that $\mathrm{ZnO}$ nanoparticles are welldistributed with the lowest agglomeration of nanoparticles (Figure 2).

The peaks at $2 \theta$ values including $31.85,34.5,36.3$, 47.65, 56.7, 62.95 with (100), (002), (101), (102), (103) and (110) diffraction, respectively are shown in the XRD patterns of $\mathrm{ZnO}$ nanoparticles (Figure 3). Furthermore, the results of XRD show the presence of $\mathrm{ZnO}$ crystals with hexagonal wurtzite structure. Average size of the synthesized $\mathrm{ZnO}$ nanoparticles was found to be $23.34 \mathrm{~nm}$ using Debye-Scherrer equation (1): $\mathrm{D}=\mathrm{k} \lambda / \beta \cos \theta$.

Where $\mathrm{k}$ is equal to $0.89 ; \lambda$ is $\mathrm{X}$-ray wavelength $(1.54 \mathrm{~A}), \beta$ is peak width at half maximum height in radian and $\theta$ is bragg diffraction angle of the maximum peak (Zhu et al., 2005; Suwanboon et al., 2013).

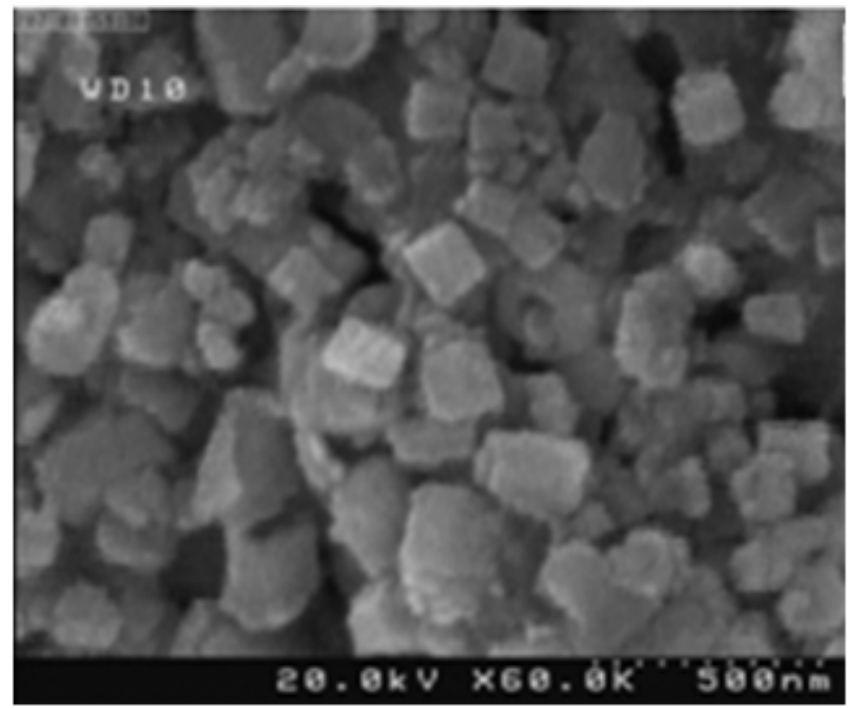

Figure 2: FESEM images of synthesized $\mathrm{ZnO}$ nanoparticles. Scale bar is $500 \mathrm{~nm}$. 


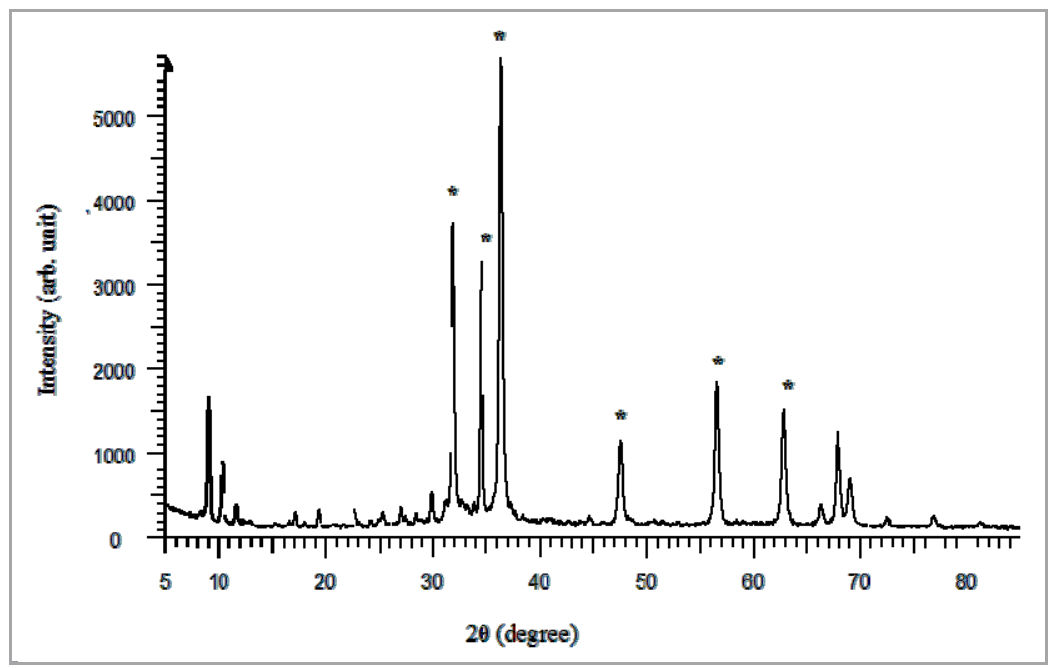

Figure 3: XRD spectrum of synthesized ZnO nanoparticles (Star symbols indicated the presence of ZnO NPs).

In FTIR spectrum of $\mathrm{ZnO}$ nanoparticles sample, two strong absorptions are seen at $503 \mathrm{~cm}^{-1}$ and $432 \mathrm{~cm}^{-1}$ in which $432 \mathrm{~cm}^{-1}$ peak represents tensile bond of $\mathrm{ZnO}$ and $503 \mathrm{~cm}^{-1}$ peak represents oxygen vacancies in $\mathrm{ZnO}$ (Figure 4).

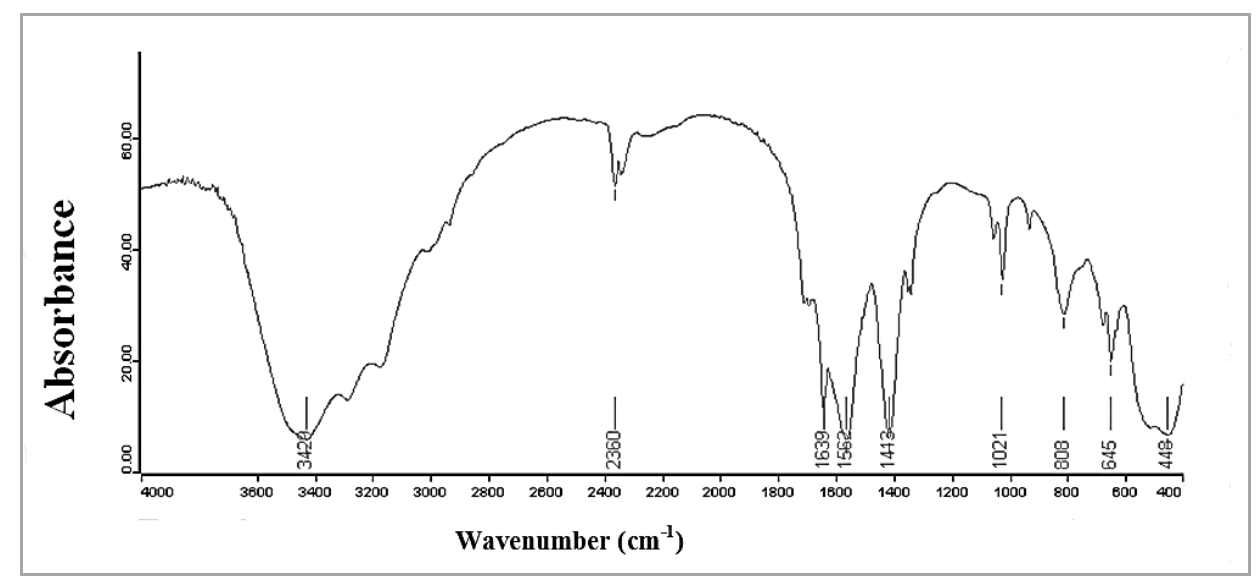

Figure 4: FTIR of synthesized $\mathrm{ZnO}$ nanoparticles

The current study revealed the positive effect of insecticidal activity of $\mathrm{ZnO}$ NPs on $T$. vaporariorum adults. Acaricidal, licicidal and larvicidal activities of the synthesized $\mathrm{ZnO}$ nanoparticles on blood - feeding parasites Rhipicephalus (Boophilus) microplus (Canestrini, 1888), Pediculus humanus capitis (De Geer,1767), Anopheles subpictus (Grassi, 1899) and Culex quinquefasciatus (Say, 1823) revealed an increase in mortality when concentration increased; moreover, considering optimal time for lethal effects of $\mathrm{ZnO}$ nanoparticles after 24 hours, it was $100 \%$ proved. In the comparison made between acaricidal, licicidal and larvicidal activities of zinc oxides and the synthesized $\mathrm{ZnO}$ nanoparticles, the mortality effect of $\mathrm{ZnO}$ nanoparticles was significant (Kirthi et al., 2011).

Rouhani et al. (2012) studied the insecticidal effects of imidacloprid, $\mathrm{Ag}$ and $\mathrm{Ag}-\mathrm{Zn}$ nanoparticles on Aphis nerii (Boyer de Fonscolombe, 1841) and $\mathrm{LC}_{50}$ values after 24 hours were seen to be $0.13 \mu 1 \mathrm{ml}^{-1}, 424.67$ and $539.46 \mathrm{mg}$ $\mathrm{ml}^{-1}$, respectively. In a similar study, Samih et al. (2011) investigated the insecticidal effect of Amitraz, $\mathrm{ZnO}$ nanoparticles and $\mathrm{ZnAl}_{2} \mathrm{O}_{3}$ against Pistachio psylly (Agonoscena pistaciae (Burckhardt and Lauterer, 1989)) and found out a 
greater insecticidal effect of Amitraz than the above nanoparticles. It should be taken into consideration that nanoparticles, especially the synthesized zinc nanopartilces, besides their insecticidal activity and also their slower effect than imidacloprid and Amitraz insecticides, have a lower risk of resistance to these nanoparticles in comparison to commercial insecticides (Rouhani et al., 2011).

Clausen et al., (2011) investigated the efficiency of $\mathrm{ZnSO}_{4}$ and $\mathrm{ZnO}$ nanoparticles on mortality of Reticulitermes flavipes (Kollar, 1837) (Isoptera, Rhinotermitidae). Their results confirmed that $R$. flavipes feeding on wood impregnated with $\mathrm{ZnO}$ nanoparticles, decreased to less than $4 \%$ in comparison to control treatment. Despite low usage of wood impregnated with $\mathrm{ZnO}$ nanoparticles, 94-99\% of mortality rate was seen in termites. In contrast, using wood impregnated with $\mathrm{ZnSO}_{4}, 10-12 \%$ was consumed and low mortality rate (10-29\%) was seen in these termites. Thus, $\mathrm{ZnO}$ nanoparticles have the necessary potential for application in wood preservatives for protecting woods against termites.

$\mathrm{LC}_{50}$ value of the synthesized $\mathrm{ZnO}$ nanoparticles on $T$. vaporariorum were consistent with the results of the above researches. Therefore, it can be said that $\mathrm{ZnO}$ nanoparticles have the necessary potential for insecticidal activity on $T$. vaporariorum and causes maximum lethality $(91.6 \%)$ at the highest concentration.

Nowadays, the only successful control strategy for the greenhouse whitefly is the combined use of pesticides and natural enemies (Hayashi, 1996); therefore, applications of some concentrations of pesticides with minimal impacts on natural enemies seem quite necessary (Laznik and Trdan, 2014). In the current study, through calculation of $\mathrm{LC}_{25}$, we can obtain a concentration of the synthesized $\mathrm{ZnO}$ nanoparticles to control $T$. vaporariorum, which is likely to distort its physiology. Since no research has been done on the impact of $\mathrm{ZnO}$ nanoparticles on natural enemies of the greenhouse whitefly, therefore, we conclude that using $\mathrm{LC}_{25}$, survival rate of $T$. vaporariorum decreases; however, this concentration would have minimal impact on natural enemies. With application of $\mathrm{LC}_{25}(3.76 \mathrm{mg}$ $\left.1^{-1}\right)$, which is quite less compared to $\operatorname{LC}_{50}(7.35 \mathrm{mg}$ $1^{-1}$ ), we can prevent the occurrence of adverse effects on natural enemies of whiteflies.

Based on new and significant properties of nanoparticles, these materials are widely used in industrial and agricultural sectors; therefore, assessment of their potential toxic effects on human health and environment seems quite necessary (Auffan et al., 2009). As a discussion, the best approach to avoid adverse effects on the environment and ecotoxicological effects of nanoparticles on beneficial insects such as parasitoids wasps is using low concentrations of nanoparticles to control pest insects such as $T$. vaporariorum.

\subsection{Bioassay of $B$. bassiana TS11}

The results obtained from statistical analysis of bioassays on the greenhouse whitefly revealed the susceptibility of $T$. vaporariorum adults to $B$. bassiana TS11 isolate; however, the amount of mortality was different based on determined spore concentrations. More than $50 \%$ of mortality was observed in concentrations of $10^{6}, 10^{7}$ and $10^{8}$ spores $\mathrm{ml}^{-1}$ during the experimental period (10 days). Generally, the least amount of mortality after 10 days was obtained with $10^{4}$ spore $\mathrm{ml}^{-1}$ concentration with an average of $33.3 \%$. Mortality rate of whiteflies depended on concentration and mortality rate increased along with the increase in concentration. Maximum mortality $(88.8 \%)$ rate was obtained with $10^{8}$ spore $\mathrm{ml}^{-1}$. In concentrations of $10^{5}, 10^{6}$ and $10^{7}$ spore $\mathrm{ml}^{-1}$, the mortality rates were seen to be $42.2 \%, 58.8 \%$ and $78.8 \%$, respectively (Figure 5). Statistically, a significant difference was seen between concentrations of $10^{5}$ and $10^{6}$ spore $\mathrm{ml}^{-1}$. However, in terms of mortality rate, there were no significant differences between concentrations of $10^{7}$ and $10^{8}$ and concentrations of $10^{4}$ and $10^{5}$ spore $\mathrm{ml}^{-1}$. 


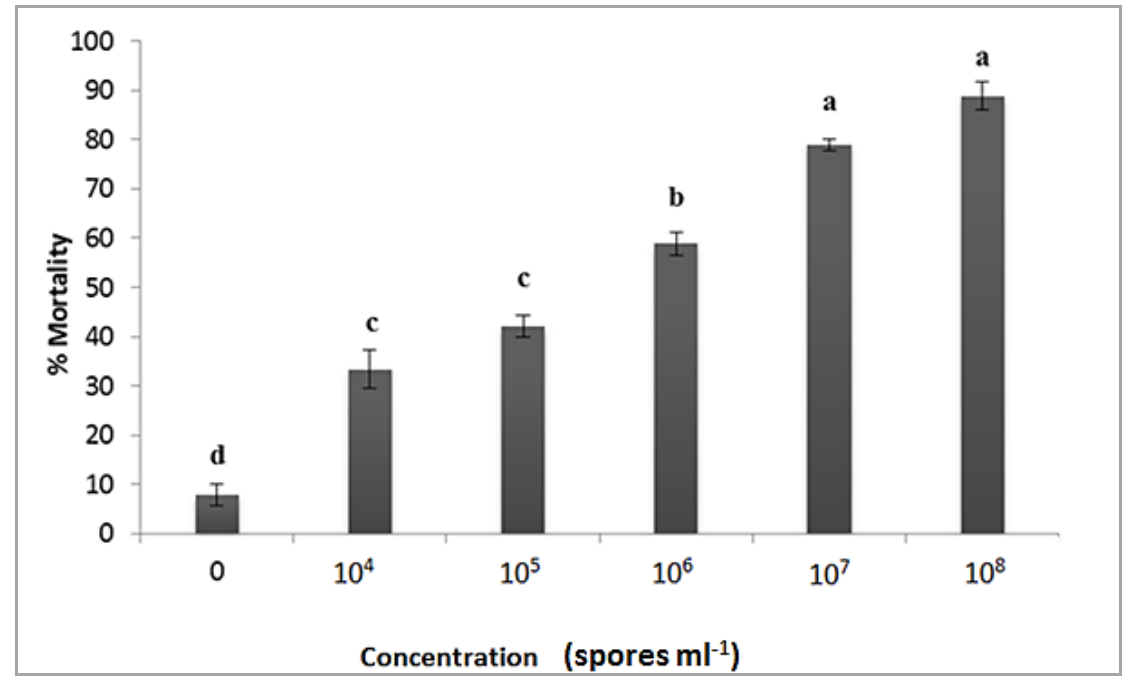

Figure 5: Mean of mortality of T.vaporariorum adults 10 days after treatment by B.bassiana

Among all antimicrobial agents, entomopathogenic fungi due to frequency in pathogenic races, broad host range and methods of pathogenicity can control a broad range of pests (Fan et al., 2007). The current study revealed that B. bassiana TS11 isolate can lead to infection and mortality of $T$. vaporariorum. Several studies have reported $B$. bassiana to control agricultural pests such as Tetranychus cinnabarinus (Boisduval, 1867) (Shi and Feng, 2004), Chilo partellus (Swinhoe, 1885) (Tefera and Pringle, 2004), whiteflies (Wraight et al., 1998, 2000; Ramos et al., 2000; Mascarin et al., 2013), Helicoverpa zea (Boddie, 1850), Spodoptera exigua (Hubner,1808), Spodoptera frugiperda (J.E. Smith, 1797) (Wraight et al., 2010), and Aelia rostrata (Boheman, 1852) (Mustu et al., 2011). Khosravi et al., (2014) studied the pathogenicity of four isolates, IRAN 403C, SP 566, SPT 22 and IR-K-40 of B. bassiana on Arge rosae (Linnaeus 1970). The results showed the great effect of these isolates on this hymenopteran species; however, IRAN $403 \mathrm{C}$ isolate with $\mathrm{LC}_{50}$ value of $5.54 \times 10^{5}$ spore $\mathrm{ml}^{-1}$ and mortality rate of $82.5 \%$ was highly more effective.

Mascarin et al., (2013) reported that B.bassiana CG1229 isolate in a concentration of $1 \times 10^{7}$ spore $\mathrm{ml}^{-1}$ led to more than $80 \%$ of mortality rate in silver-leaf whitefly (Bemisia argentifolii (Gennadius, 1889)) populations. Therefore, B.bassiana has a high pathogenicity potential for this insect while it can significantly control this whitefly (Mascarin et al., 2013).

In the present study, $B$. bassiana TS11 had a significant pathogenic effect on $T$. vaporariorum adults, because it had a low $\mathrm{LC}_{50}$ value and led to high mortality rate $(88.8 \%)$ in concentration of $10^{8}$ spore $\mathrm{ml}^{-1}$. Mortality in control treatment was so low and no fungal growth was seen on dead adult whiteflies. In terms of pathogenicity of $B$. bassiana for $T$. vaporariorum, similar to the effects of synthesized $\mathrm{ZnO}$ nanoparticles, calculation of lethal concentrations such as $\operatorname{LC}_{25}\left(0.106 \times 10^{5}\right.$ spore $\mathrm{ml}^{-1}$ ) is in turn particularly important.

We should pay attention to the interactions of the entomopathogenic fungi and whiteflies natural enemies (i.e. Encarsia spp., Eretmocerus spp., etc.) to minimize adverse effects on them. Therefore, despite the best effect of $B$. bassiana on pest insects such as $T$. vaporariorum, we should also take into account the low lethal effects of this entomopathogenic fungus so that they have minimal impact on natural enemies.

\section{CONCLUSION}

The current study was performed to demonstrate the insecticidal effects of $\mathrm{ZnO}$ nanoparticles and $B$. bassiana on the greenhouse whitefly. The obtained results proved the efficiency of synthetic 
nanoparticles and entomopathogenic fungi as effective control agents, which can lead also to the delay in pest resistance mechanisms to chemical insecticides. It is possible that by adding nanoparticles and entomopathogenic fungi to formulations of insecticides, toxicity of chemical insecticides for humans and other non-target organisms would be mitigated. Further study will need to focus on methods to increase stability and on physiological mechanisms of nanoparticles and entomopathogenic fungi interactions to increase their effects in integrated pest management programs at large greenhouse and field levels.

\section{ACKNOWLEDGMENT}

The authors are grateful to Department of Plant Protection and Department of Chemistry,
University of Zabol, Iran, for financing and providing the laboratory facilities.

\section{REFERENCES}

AbdElhady M.M. 2012. Preparation and characterization of chitosan/zinc oxide nanoparticles for imparting antimicrobial and UV protection to cotton fabric. International Journal of Carbohydrate Chemistry: 1-6. Retrieved from DOI: 10.1155/2012/840591.

Auffan M., Rose J., Bottero J.Y., Lowry G.V., Jolivet J.P., Wiesner M.R. 2009. Towards a definition of inorganic nanoparticles from an environmental, health and safety perspective. Nat. Nanotechnol. 4: 634-641. DOI: 10.1038/nnano.2009.242.

Brayner R., Ferrari-Iliou R., Brivois N., Djedia S., Benedetti M.F., Fievet F. 2006. Toxicological impact studies based on Escherichia coli bacteria in ultra $\mathrm{ZnO}$ nanoparticles colloidal medium. Nano. Lett. 6: 866.

Chaudhry Q., Scotter M., Blackburn J., Ross B., Boxall A., Castle L., Aitken R., Watkins R. 2008. Applications and implications of nanotechnologies for the food sector. Food Addit. Contam. A 25 (3): 241-258. DOI: 10.1080/02652030701744538.

Clausen C.A, Kartal. SN., Arango R.A., Green F. 2011. The role of particle size of particulate nano-zinc oxide wood preservatives on termite mortality and leach resistance. Nanoscale Res. Lett. 6: 42. DOI: 10.1186/1556-276X-6-427.

El-Sinary N.H., Rizk S.A. 2007. Entomopathogenic fungus, Beauveria bassiana (Bals.) and gamma irradiation efficiency against the greater wax moth, Galleria melonella (L.). Am-Euras. J. Sci. Res. 2 (1): 13-18.

Fan Y., Fang W., Guo S., Pei X., Zhang Y., Xiao Y., Li D., Jin K., Bidochka M.J., Pei Y. 2007. Increased insect virulence in Beauveria bassiana strains overexpressing an engineered chitinase. Appl.
Environ. Microbiol. 73(1): 295-302. DOI:10.1128/AEM.01974-06.

Goswami A., Roy I., Sengupta S., Debnath N. 2010. Novel applications of solid and liquid formulations of nanoparticles against insect pests and pathogens. Thin Solid Films. 519 (3): 1252-1257. DOI:10.1016/j.tsf.2010.08.079.

Gupta A.K., Gupta M. 2005. Synthesis and surface engineering of iron oxide nanoparticles for biomedical applications. Biomaterials. 26 (18): 3995-4021.

DOI:10.1016/j.biomaterials.2004.10.012.

Gurulingappa P., McGee P.A., Sword G. 2011. Endophytic Lecanicillium lecanii and Beauveria bassiana reduce the survival and fecundity of Aphis gossypii following contact with conidia and secondary metabolites. Crop Prot. 30: 349 - 353. DOI: 10.1016/j.cropro.2010.11.017.

Guzman P., Arredondo C.R., Emmatty D., Gilbertson R.L. 1997. Partial characterization of two whiteflytransmitted geminiviruses infecting tomatoes in Venezuela. Plant Dis. 81 (3): 312-318. Retrieved from DOI: 10.1094/PDIS.1997.81.3.312A.

Hayashi H. 1996. Side effects of pesticides on Encarsia Formosa Gahban. Bulletin of the Hiroshima Prefectural Agriculture Research Center. 64: 33-43.

Inglis G.D., Goettel M.S., Butt T.M., Strasser H. 2001. Use of hyphomycetous fungi for managing insect pests. In Butt T.M., Jackson C., Magan, N. (Eds), Fungi as biocontrol agents: progress problems and potential (pp. 23-69). New York: CABI.

Kairyte K., Kadys A., Luksiene Z. 2013. Antibacterial and antifungal activity of photoactivated $\mathrm{ZnO}$ nanoparticles in suspension. J. Photochem.

Acta agriculturae Slovenica, 107 - 2, september 2016 
$\begin{array}{llll}\text { Photobiol. } & \text { B. } & \text { 128: }\end{array}$ DOI:10.1016/j.jphotobiol.2013.07.017.

Khosravi R., Sendi J.J., Zibaee A., Shokrgozar M.A., 2014. Virulence of four Beauveria bassiana (Balsamo) (Asc., Hypocreales) isolates on rose sawfly, Arge rosae under laboratory condition. J. King Saud Uni-Sci 27 (1): 49-53. Retrieved from DOI: $10.1016 /$ j.jksus.2014.04.003.

Kirthi A.V., Rahuman A.A., Rajakumar G., Marimuthu S., Santhoshkumar T., Jayaseelan C., Velayutham K. 2011. Acaricidal, pediculocidal and larvicidal activity of synthesized $\mathrm{ZnO}$ nanoparticles using wet chemical route against blood feeding parasites. Parasitol. Res. 109: 461-472. DOI: 10.1007/s00436-011-2277-8.

Lacey L.A., Frutos R., Kaya H.K., Vail P. 2001. Insect pathogens as biological control agents: Do they have a future?. Biol. Control. 21 (3): 230-248. DOI: 10.1006/bcon.2001.0938.

Laznik Z., Trdan S. 2014. The influence of insecticides on the viability of entomopathogenic nematodes (Rhabditida: Steinernematidae and Heterorhabditidae) under laboratory conditions. Pest Manag. Sci. 70(5): 784-789. DOI: $10.1002 /$ ps.3614.

Laznik Z., Znidarcic D., Trdan S. 2011. Control of Trialeurodes vaporariorum (Westwood) adults on glasshouse-grown cucumbers in four different growth substrates: An efficacy comparison of foliar application of Steinernema feltiae (Filipjev) and spraying with thiamethoxam. Turk. J. Agric. For. 35: 631-640. DOI: 10.3906/tar-1007-1110.

Lozano-Gutierrez J., Espana-Luna M. 2008. Pathogenicity of Beauveria bassiana (Deuteromycotina: Hyphomycetes) against the white grub Laniifera cyclades (Lepidoptera: Pyralidae) under field and greenhouse conditions. Fla. Entomol. 91 (4): 664-668. Retrieved from DOI: 10.1653/0015-4040-91.4.664.

Magrez S., Kasas V., Salicio N., Pasquier J., Seo W., Celio M., Catsicas S., Schwaller B., Forro L. 2006. Cellular toxicity of carbon-based nanomaterials. Nano Lett. 6 (6): 1121-1125. DOI: 10.1021/n1060162e.

Manzo S., Rocco A., Carotenuto R., Picione F.D.L., Miglietta M.L., Rametta G.D., Francia G. 2011. Investigation of $\mathrm{ZnO}$ nanoparticles'ecotoxicological effects towards different soil organisms. Environ. Sci. Pollut. Res. 18: 756-763. DOI: 10.1007/s11356-010-0421-0.

Mascarin G.M., Kobori N.N., Quintela E.D., Delalibera J.I. 2013. The virulence of entomopathogenic fungi against Bemisia tabaci biotype B (Hemiptera: Aleyrodidae) and their conidial production using solid substrate fermentation. Biol. Control. 66: 209218. DOI: 10.1016/j.biocontrol.2013.05.001.

Mitra S., Chandra S., Laha D., Patra P., Debnath N., Pramanik A., Pramanik P., Goswami A., 2012. Unique chemical grafting of carbon nanoparticle on fabricated $\mathrm{ZnO}$ nanorod: Antibacterial and bioimaging property. Mater Res. Bull. 47 (3): 586594. DOI: 10.1016/j.materresbull.2011.12.036.

Morones J.R., Elechiguerra J.L., Camacho A., Holt K., Kouri J.B., Ramirez J.T., Yacaman M.J. 2005. The bactericidal effect of silver nanoparticles. Nanotechnology. $16 \quad$ (10): 2346. DOI: 10.1088/0957-4484/16/10/059.

Muniz M., Nombela G. 2001. Differential variation in development of the B - and Q - Biotypes of Bemisia tabaci (Homoptera: Aleyrodidae) on sweet pepper at constant temperatures. Environ. Entomol. 30 (4): 720-727. Retrieved from DOI: 10.1603/0046225X-30.4.720.

Mustu M., Demirci F., Kocak E. 2011. Mortality effects of Isaria farinosae (Holm.) and Beauveria bassiana (Balsamo) Vuillemin (Sordariomycetes: Hypocreales) on Aelia rostrata Boh. (Hemipterab: Pentatomidae). Turkish Journal of Entomology. 35(4): 559-568.

Rai M., Ingle A. 2012. Role of nanotechnology in agriculture with special reference to management of insect pests. Appl. Microbiol. Biotechnol. 94: 287293.

Ramos E.Q., Alves S.B., Tanzini M.R., Lopes R.B. 2000. Susceptibilidade de Bemisia tabaci a Beauveria bassiana en condiciones de laboratorio. Manejo Integrado de Plagas. 56: 65-69.

Reddy K.M., Feris K., Bell J., Wingett D.G., Hanley C., Punnoose A. 2007. Selective toxicity of zinc oxide nanoparticles to prokaryotic and eukaryotic system. Appl. Phys. Lett. 90: 213902. Retrieved from DOI: 10.1063/1.2742324.

Rouhani M., Samih M.A., Aslani A., Beiki K. 2011. Side effect of nano-ZnO - Tio2 - Ag mix-oxide nanoparticles on Frankliniella occidentalis Pergande (Thys.: Thripidae). In Proceedings Symposium: Third International Symposium on Insect Physiology, Biochemistry and Molecular Biology. East China Normal University, Shanghai, China. 2-5.

Rouhani M., Samih M.A., Kalantari S. 2012. Insecticide effect of silver and zinc nanoparticles against Aphis nerii boyer de fonscolombe (Hemiptera: Aphididae). Chilean JAR. 72 (4): 590-594. 
Samih M.A., Rouhani M., Aslani A., Beiki K., 2011. Insecticidal properties of amitraz, nano - amitraz, nano $-\mathrm{ZnO}$ and nano $-\mathrm{ZnO}-\mathrm{Al}_{2} \mathrm{O}_{3}$ nanoparticles on Agonoscena pistaciae (Hem.: Aphelaridae). In Proceedings Symposium: Third International Symposium on Insect Physiology, Biochemistry and Molecular Biology. East China Normal University. Shanghai, China. 131.

Samuel U., Guggenbichler J.P. 2004. Prevention of catheter-related infections: The potential of a new nano - silver impregnated catheter. Int. J. Antimicrob. Ag. 23 (1): 75-78. DOI: 10.1016/j.ijantimicag.2003.12.004.

Sandhu S.S., Sharma A.K., Beniwal V., Goel G., Batra P., Kumar A., Jaglan S., Malhotra S., 2012. Myco Biocontrol of insect pests: Factors involved, mechanism and regulation. J. Pathogens. 1-10. DOI: $10.1155 / 2012 / 126819$.

Sewify G.H., Belal M.H., Al-Awash S.A. 2009. Use of the entomopathogenic fungus, Beauveria bassiana for the biological control of the red palm weevil, Rhynchophorus ferrugineus Olivier. Egypt J. Biol. Pest Control. 19 (2): 157-163.

Shi W.B., Feng M.G. 2004. Lethal effect of Beauveria bassiana, Metarhizium anisopliae and Paecilomyces fumosoroseus on the eggs of Tetranychus cinnabarinus (Acari: Tetranychidae) with a description of a mite egg bioassay system. Biol. Control. 30 (2): 165-173. DOI: 10.1016/j.biocontrol.2004.01.017.

Suwanboon S., Amornpitoksuk P., Sukolrat A., Muensit N. 2013. Optical and photocatalyctic properties of La-doped $\mathrm{ZnO}$ nanoparticles prepared via precipitation and mechanical milling method. Ceram Int. 39: 2811-2819. DOI: 10.1016/j.ceramint.2012.09.050.

Tefera T., Pringle K.L. 2004. Evaluation of Beauveria bassiana and Metarhizium anisopliae for controlling Chilo partellus (Lepidoptera: Crambidae) in Maize. Biocontrol Sci. Techn. 14 (8): 849-853. DOI: 10.1080/0958315041000172707.

Umar A., Rahman A., Vaseem M., Hahn Y.B. 2009. Ultra-sensitive cholesterol biosensor based on low temperature grown $\mathrm{ZnO}$ nanoparticles. Electrochem. Commun. 11 (1): 118-121. DOI: 10.1016/j.elecom.2008.10.046.
Van Lenteren J.C., Van Roermund H.J.W., Sutterlin S., 1996. Biological control of Greenhouse whitefly (Trialeurodes vaporariorum) with the Parasitoid Encarsia formosa: How does it work?. Biol Control. 6 (1): 1-10. DOI: 10.1006/bcon.1996.0001.

Velayutham K., Rahuman A.A., Rajakumar G., Roopan S.M., Elango G., Kamaraj C., Siva C. 2013. Larvicidal activity of green synthesized silver nanoparticles using bark aqueous extract of Ficus racemosa against Culex quinquefasciatus and Culex gelidus. Asian Pac. J. Trop. Med. 95-101. DOI: 0.1016/S1995-7645(13)60002-4.

Whalon M.E., Mota-Sanchez D., Hollingworth R.M. 2008. Analysis of global pesticide resistance in arthropods. In Whalon M.E., Mota-Sanchez D., Hollingworth R.M. (Eds.), Global pesticide resistance in Arthropods (pp. 5-31). CABI, Wallingford, UK.

Wraight S.P., Carruthers R.I., Bradley C.A., Jaronski S.T., Lacey L.A., Wood P., Galaini-Wraight S. 1998. Pathogenicity of the entomopathogenic fungi Paecilomyces spp. and Beauveria bassiana against the silverleaf whitefly, Bemisia argentifolii. J. Invertebr. Pathol. 71: 217-226. DOI: 10.1006/jipa.1997.4734.

Wraight S.P., Carruthers R.I., Jaronski S.T., Bradley C.A., Garza C.J, Galaini-Wraight S. 2000. Evaluation of the entomopathogenic fungi Beauveria bassiana and Paecilomyces fumosoroseus for microbial control of the silverleaf whitefly, Bemisia argentifolii. Biol. Control. 17: 203-217. DOI: 10.1006/bcon.1999.0799.

Wraight S.P., Ramos M.E., Avery P.B., Jaronski S.T., Vandenberg J.D. 2010. Comparative virulence of Beauveria bassiana isolates against lepidopteran pests of vegetable crops. J. Invertebr. Pathol. 103: 186-199. DOI: 10.1016/j.jip.2010.01.001.

Zhang L., Jiang Y., Ding Y., Povey M., York D. 2007. Investigation into the antibacterial behaviour of suspensions of $\mathrm{ZnO}$ nanoparticles $(\mathrm{ZnO}$ nanofluids). J. Nanopart. Res. 9 (3): 479-489. DOI: 10.1007/s11051-006-9150-1.

Zhu Y., Yu F., Man Y., Tian Q., He Y., Wu N. 2005. Preparation and performances of nanosized $\mathrm{Ta}_{2} \mathrm{O}_{5}$ powder photocatalyst. J. Solid State Chem. 178: 224-229. DOI: 10.1016/j.jssc.2004.11.015.

Acta agriculturae Slovenica, 107 - 2, september 2016 